\title{
先天性乏毛症が認められた雑種猫の一例
}

\section{Congenital Hypotrichosis in a Domestic Cat}

\author{
財家あすみ ${ }^{1)} * \quad$ 石井 $^{\text {聡 }}{ }^{1)} \quad$ 賀川由美子 ${ }^{2)}$ 村山信雄 $^{3)}$ \\ 1) 石井どうぶつ病院， ${ }^{2)}$ NORTH LAB， ${ }^{3)}$ 犬と猫の皮膚科 \\ Asumi Zaike $^{1)}$, Satoshi Ishii $^{1)}$, Yumiko Kagawa ${ }^{2)}$, Nobuo Murayama ${ }^{3)}$ \\ ${ }^{1)}$ Ishii Animal Hospital, ${ }^{2)}$ NORTH LAB, ${ }^{3)}$ Dermatology Services for Dogs and Cats
}

Received November 13, 2018 and accepted December 28, 2018

先天性乏毛症は，犬や猫で非常に稀な疾患であ り, 猫では, バーマン, バーミーズ，デボン・レッ クス，拉よびシャムで報告されている ${ }^{3)}$ 。本症は， 同腹子のうち 1 頭または複数頭でみられ, 出生時, または 1 ケ月齢より生じる脱毛であり，頭部や体 幹で左右対称性に局所性または沉発性にみられ る ${ }^{2)}$ 。本例の多くが雄であることから，性別と関 連する遺伝子の変異が原因であることが示唆され ている4)。また症例のなかには, 歯牙発生の異常 や涙の異常産生など他の遺伝的な外肧葉異常が認 められることもある ${ }^{4)}$ 。今回, 出生時よりそ毛を 認めた雑種猫に遭遇したことから，その概要を報 告する。

8 ケ月齢, 未去勢雄, サバトラの二毛（シルバー マッカレル\&ホワイトのバイカラー）の毛色をし た雑種猫が，略全身の薄毛を主訴に受診した。本 例は, 本例と同様の毛色の雑種猫の雄と, 黒 (ブラッ クソリッド）の毛色の雑種猫の雌との間に生まれ, 両親の被毛はいずれも健常であった。同腹子は, 白（ホワイトソリッド）の毛色の雌 1 頭, 本例と 同様の毛色の雄雌各 1 頭の 3 頭であり, いずれも 被毛は健常であったが, 本例のみ, 出生時より頭 部を主体に脱毛がみられた（図 1a)。出生時には同 腹子との体格差はなかったが, 生後 2 ケ月間は発 育が悪く，39日齢で低体温と虚脱を主訴に受診さ れ, 体重 $380 \mathrm{~g}$ と贏瘦していた（ボディ・コンディ ション・スコア 2/5)（図 1b)。当初は屋外飼育であっ たが, 室内飼育としたところ, 順調に発育し（図

*連絡先：財家あすみ（石井どうぶつ病院）

干 262-0045 千葉県千葉市花見川区作新台 6-18-34

TEL · FAX 043-286-8777

E-mail: ishiiah@icloud.com 1c），8 ケ月齢まで受診はなかった。

今回受診時にも, 略全身に薄毛がみられ, 残存 する毛は一次毛が主体であった（図 2，3）。身体 検査では, 歯, 涙の産生, 爪の形態, 心血管系も 含めて, 特記すべき異常はみられなかった(体重 3.0 $\mathrm{kg}$, ボディ・コンディション・スコア $3 / 5)$ 。鑑別 疾患として, 感染症 (皮膚糸状菌症, 二キビダ二症), 内分泌疾患 (甲状腺機能低下症など), および先天 性乏毛症などが考えられた。血液一般検査および 血液生化学検査で特記すべき異常なく, 血清総サ イロキシン $1.8 \mu \mathrm{g} / \mathrm{dl}$ (アイデックスラボラトリー ズ株式会社 SNAPshotDx)，抢よび遊離サイロキシ ン $17.2 \mathrm{ng} / \mathrm{dl}$ (アイデックスラボラトリーズ株式会 社）であった。胸腹部 X 線検査や毛検査において も異常は認めなかった。頸部背側, 右肩, および 腰部背側から採材された皮膚病理検査では, 表皮 と真皮には異常は認められないものの, いずれの 部位でも毛包構造や皮膚付属器はわずかに観察さ れるのみで，明らかな減少を認めた（図 4a)。残 存する毛包は形態学的に特に異常のない成長期の 一次毛であり，二次毛はみられなかった（図 4b)。 臨床像抢よび諸検査から先天性乏毛症と診断した。 一般状態に問題がなかったことから，ご家族と相 談のうえ，経過観察となった。

そ毛の鑑別疾患として, 外胚葉異形成, 感染症, および内分泌疾患などが考えられる。本例は脱毛 以外に身体的異常がみられなかった。また血液検 査や甲状腺ホルモンで異常はなく, 皮膚病理検査 では, 炎症細胞の浸潤は認められなかった。組織 学的には, 毛包の著しい減少を特徵とし, 先天性 乏毛症に合致した所見であった。先天性乏毛症と 診断されたバーマンでは, FOXN1 遺伝子の欠如が 


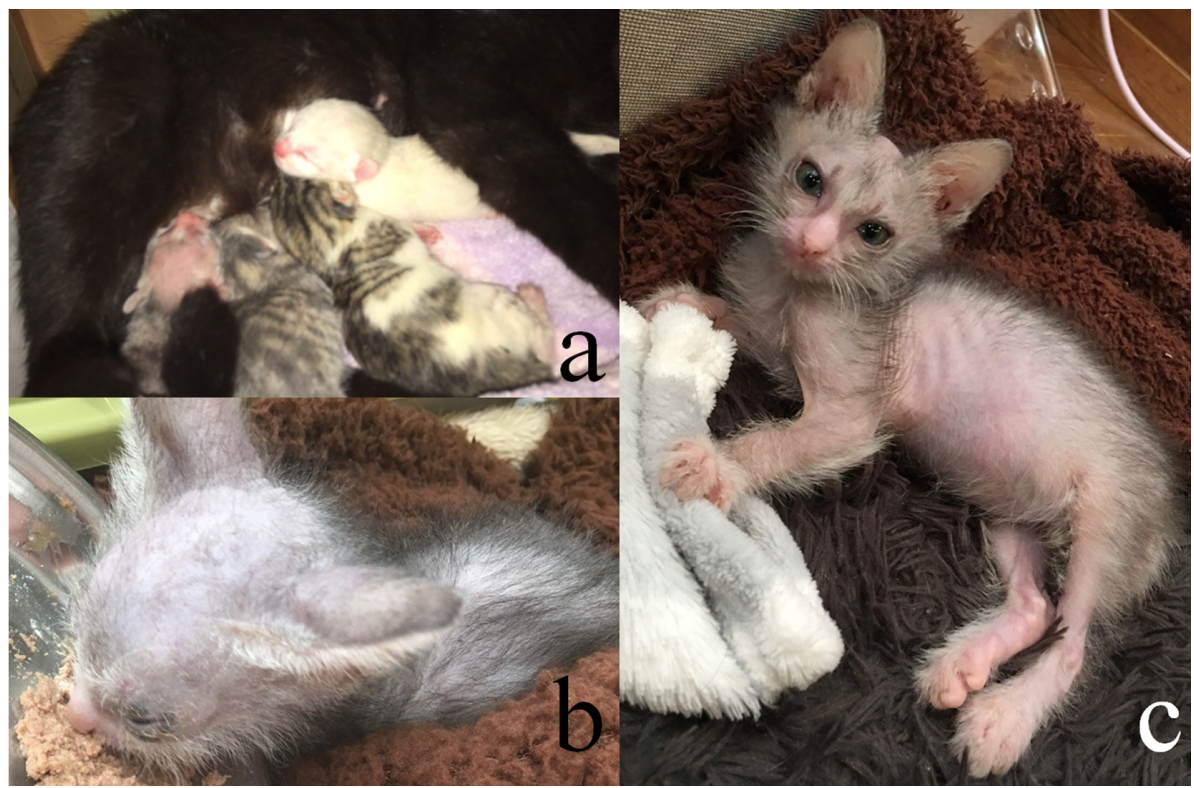

図 $1 \mathrm{a}: 1$ 日齢。母猫および同腹子 3 頭と本症例 (一番左)。同腹仔とは異なり, 出 生時に頭部に脱毛がみられた。b：39 日齢。頭部だけではなく，体幹にも薄毛 が観察された。 c：83 日齢。略全身に薄毛がみられた。

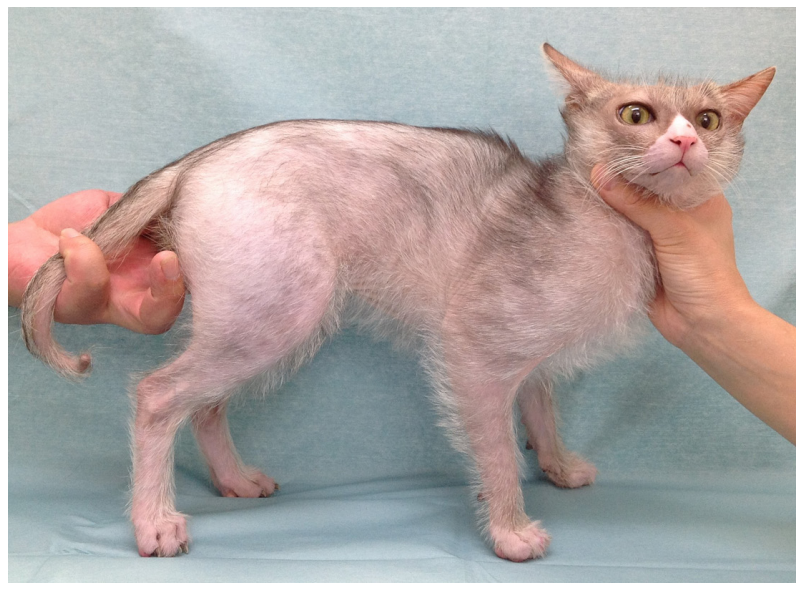

図 2 生後 8 ケ月（皮膚病理検査時）。略全身に薄毛が みられ, 一次毛が残存していた。

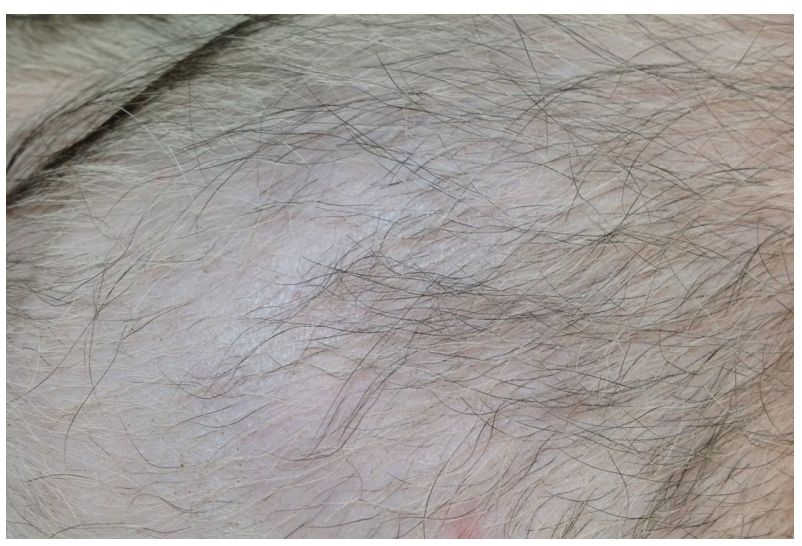

図 3 病理組織検査を実施した右肩部の拡大像。一次毛 のみ残存していた。

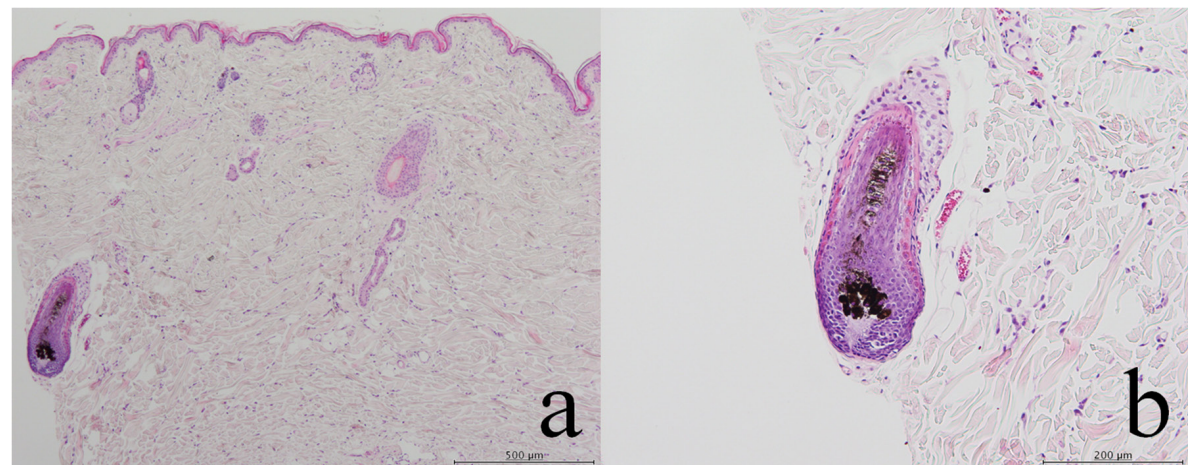

図 $4 \mathrm{a}$ : 皮膚病理組織像. わずかに一次毛が観察されるのみであった。残存していた一次毛で は特記すべき異常はみられなかった。 $\mathrm{b}$ : 皮膚病理組織像. 残存していた一次毛の拡大像. 
指摘されており，乏毛だけではなく，短命であっ た ${ }^{1)}$ 。本症例でも乏毛ともに, 生後直後の虚弱や 発育遅延などがみられたが，9ケ月齢で受診され た際には，歯牙などの他の外肧葉性の異常も含め, 乏毛以外の異常所見はなく, バーマンの報告例と は異なる経過を辿っている。また, YPCマウスでは, 毛形成異常と毛周期異常により, 生後より貧毛お よび縮毛を呈するが, 本症例は, 存在する毛に縮 毛や毛周期異常などは認められない5)。また, ヒ 卜の先天性乏毛症では, LIPH 遺伝子変異による常 染色体劣性遺伝形式の縮毛症およびそ毛症を呈し, 生下時は正常であるが, 徐々に脱毛が進み, 細い 毛が疎らに生えている状態になる ${ }^{6)}$ 。本症例では, 生下時から毛が見られ, 縮毛はなく, また, 存 在する毛は一次毛で細くない点が異なる。猫での 本疾患は雄で多く認められており, 本例も雄であ ることから，性別と関連した遺伝子変異が予想さ れた。今後, 遺伝学的解析を含め, 本症の病因の 特定を検討したい。

\section{利益相反}

すべての著者は開示すべき利益相反はない。

\section{引用文献}

1) Abitbol, M., Bosse, P., Thomas, A., Tiret, L., 2015. PLoS. ONE. 10(3): e0120668.doi:10.1371/journal. pone. 0120668 .

2) Hnilica, Kwith A. 2011.pp. 316. In: SMALL ANIMAL DERMATOLOGY, 3rd ed., Saunders, Philadelphia.

3）斑目広郎，金安まゆ久翻訳．2002。pp. 16.216.3. PRACTICAL GUIDE 猫の皮膚科学 (小方 宗次監修),メリアル・ジャパン株式会社, 東京.

4) 日本獣医皮膚科学会監訳。2009。pp 531-533. 犬と猫の皮膚病, 第 2 版, インターズー, 東京.

5) Okada, T., Ishii, Y., Masujin, K., Yasoshima, A., Matsuda, J., Ogura, A., Nakayama, H., Kunieda, T. and Doi, K. 2006. Am. J. Pathol. 168: 1119-1133.

6) 清水 宏. 2018. pp 371. あたらしい皮膚科学, 第 3 版，中山書店，東京. 